\title{
From Common Reader to Canon: Memorialising the Shakespeare-Reading British Soldier During the First World War
}

\author{
Edmund G. C. King
}

In October 1916, the Shakespeare biographer Sir Sidney Lee wrote to The Times. He had just received a letter from a soldier serving 'somewhere in France'. Seconding Lee's observation, in an earlier letter to The Times, that military personnel attending London theatres wanted more than mere 'futility and frivolity', Lee's soldier correspondent lamented the fact that 'so many people seem to think there is no room or place for good drama' during wartime. 'This is my second autumn out here', he told Lee, 'and somehow I manage to cart around my Shakespeare'. Even when circumstances demanded that he leave his collected Shakespeare behind, he wrote, 'my memory is fairly good and I browse there'. ' Three years earlier, in his inaugural professorial lecture at East London College, Lee had urged his future students to take advantage of 'these days of cheap reprints' and form their own private libraries of classic works. Ending his address on a rousing note, he looked forward to a time when study and 'right reading' would enable them to 'spread far and wide in the outer world the glad tidings of literature's saving grace'. ${ }^{2}$

E. G. C. King $(\bowtie)$

English and Creative Writing, The Open University, Milton Keynes, UK e-mail: edmund.king@open.ac.uk

(C) The Author(s) 2021

E. G. C. King and M. Smialkowska (eds.), Memorialising Shakespeare, Palgrave Shakespeare Studies, https://doi.org/10.1007/978-3-030-84013-6_2 
In Lee's hands, the letter from the front-he does not reveal whether its author was a former East London College student-represents something like a fulfilment of that call. With it, Lee takes aim at the proprietors of contemporary London theatres, urging them to return to more serious drama in the interests of patriotic necessity. 'The nation owes it to its soldiers', he wrote, 'to provide something beyond inanity and vulgarity for their amusement' (Lee, 'Drama for Soldiers', p. 9).

Lee's letter was only one of many assertions in the British press during the First World War that British soldiers possessed a particular taste for Shakespeare. Publicity material issued by book charities like the Camps' Library and the British Red Cross and Order of St John War Library included vignettes of the Shakespeare-reading soldier, either in the lines or wounded or sick in hospital. ${ }^{3}$ Local patriotic organisations stressed the peculiar attachment that their own soldiers had to Shakespeare and other fixtures of the English literary canon. Newspapers, meanwhile, published letters from soldiers providing first-hand descriptions of how these books were read in the field. At the same time as Shakespearean tercentenary addresses were claiming that Shakespeare epitomised English national ideals, these press dispatches seemed to prove the existence of a large audience of Shakespearean readers among those fighting for those 'ideals' in active zones. ${ }^{4}$ This chapter will examine some of these claims. It will ask how the image of the Shakespeare-reading soldier was deployed within book-trade and charity publicity and capitalised upon by educators and other members of Britain's cultural and intellectual elites. It will assess the ways in which press anecdotes about soldiers reading the classics contributed to larger discourses of national identity and cultural and aesthetic mobilisation. Finally, it will ask how these accounts may have contributed to the conflict's transmutation into a 'literary war' in post-war collective memory, one in which literature came to assume an outsized role in how war experience was subsequently 'understood, remembered and mythologized'. 5

\section{Discovering the Shakespeare-Reading Soldier}

Within a few weeks of Britain's declaration of war in August 1914, articles discussing soldiers' reading and writing habits began to appear in the British press. As one contributor to The Spectator observed, the private soldiers serving in the line were different from those who had fought Britain's previous wars. They were 'the finished product of the 
Board-schools, of free libraries and cheap books', their exposure to the education system setting them at some distance from the 'fierce ignorance of Wellington's line at Waterloo'. 6 Reading through letters from the front while compiling The War Stories of Private Thomas Atkins in late 1914, James Milne came across references to individual soldiers reading Sir Walter Scott's Marmion and John Ruskin's Crown of the Wild Olive, although he acknowledged that neither man was likely to have been 'the average soldier'. 7 Reflecting earlier accounts of the cultural horizons of British soldiers in the pre-war regular army, however, many reports of soldiers' reading tastes during the early months of the war tended to be condescending. ${ }^{8}$ A 'Lady Librarian' writing about her experiences providing books for soldiers in early 1915 suggested that most of them, regardless of education level, sought mass-market genre fiction and were generally uninterested in the traditional literary canon. The works of Dickens, Thackeray, and Bulwer-Lytton-though available in her library-were rarely, if ever, checked out. Instead, she wrote, the bulk of her customers resembled the soldier who approached the enquiries desk one day and asked for 'A story about burglars and murders, please'. The average soldier simply wanted 'a seven-penny' novel that he could fit into one of the pockets of his tunic and 'read at odd moments, without too much mental strain'. 9 Printing a summary of her article, the Edinburgh Evening News concluded from it that 'systematic literary education' was evidently 'not yet a feature of our common life', although it did express rather more understanding about the place reading might occupy in an otherwise exhausting training schedule than 'A Lady Librarian' did. 'After a hard day's work of eight hours drill', the paper asked drily, 'is it humane to ask a soldier to sit down to Dickens or Thackeray?'. ${ }^{10}$

Reports like this were part of a long tradition in English journalism of quasi-sociological investigations into working-class reading habits. ${ }^{11}$ A pervasive feature of these accounts, established by the founding essay in the tradition, Wilkie Collins's 'The Unknown Public' (1858), was their emphasis on the untrained naïveté of the new audiences for print culture produced by mass literacy. On the basis of the cheap print artefacts he surveyed, Collins concluded that the working-class consumers who bought them were 'hardly beginning, as yet, to learn to read'. ${ }^{2}$ In both 'The Unknown Public' and the later studies it inspired, the working classes are depicted as perpetual newcomers to reading, in need of constant supervision and guidance. They eternally arrive at, but never move beyond, basic literacy. These assumptions about working-class 
literacy were widely shared and resilient. Middle-class observers of ordinary soldiers' reading and writing practices in the first months of the war perpetuated the same ideas. A Spectator contributor, writing about the gulf between form and feeling in soldiers' letters, ascribed it partly to the fact that 'expression upon paper is difficult to those unaccustomed to it'. ${ }^{13}$ In her Daily Chronicle article, 'A Lady Librarian' attributed her customers' preference for Florence Barclay and Charles Garvice over Rudyard Kipling partly to the fact that Kipling's 'style' was 'too elusive to be readily understood by an untrained intelligence' ('A Lady Librarian', p. 6).

As the war continued beyond its first winter, however, a different picture of British military reading practices began to emerge in newspaper publicity. Evidently responding to one of the early press reports on soldiers' reading tastes, one Sergeant Galbraith of the Royal Scots Fusiliers wrote to the Aberdeen Evening Press in January 1915 to complain. 'Don't run away with the impression that soldiers never read anything but trash', he cautioned. Carlyle, Ruskin, and Matthew Arnold were widely read both on the battlefield and in hospital and 'the works of Shakespeare are carried by hundreds of men', alongside those of Thomas Hardy and George Meredith. ${ }^{14}$ The Academy reprinted an anecdote about a 'private in the 10th Royal Fusiliers or some such regiment' seeking out a copy of Dante's Inferno 'because he had never had time to read Dante before'. Other books that the Academy's columnist had heard were popular among British soldiers in the lines in 1915 included Jane Austen's Emma and the Meditations of Marcus Aurelius, although Shakespeare was reportedly 'not very widely read' among soldiers, 'perhaps because the Huns seem to have a penchant for him'. The Academy intervened at this point on Shakespeare's behalf, suggesting that Shakespeare was 'hardly an author who lends himself to reading in scraps' during the discontinuous moments of spare time an ordinary soldier might have. ${ }^{15}$

Other commentators were more insistent about Shakespeare's popularity among military readers. A correspondent to the Arbroath Herald invited readers to bear in mind that 'men at the front prefer the best' books on offer. While officers might read cheap reprint editions of classic literature, readers of Palgrave's Golden Treasury could be found among the common soldiers of every battalion, and 'single plays of Shakespeare are prized'. ${ }^{16}$ The novelist Beatrice Harraden, honorary librarian at the suffragette-staffed Endell Street Military Hospital in London, commented on the extreme popularity of the racing novels of Nat Gould among 
the wounded patients convalescing there in late 1915. However, she continued, while one man might be absorbed in Gould, 'the man in the next bed would be reading Shakespeare, or "The Pilgrim's Progress", or Shelley, or Meredith, Conrad, or the Encyclopedia'. Overall, she claimed, based on what she had seen, 'Shakespeare holds his own surprisingly and encouragingly well'. ${ }^{17}$ The tension between 'surprise' and 'encouragement' in Harraden's account captures the ambiguity of many of these reports, the sense that their observers are combining documentary evidence with their own desire for wish fulfilment. Harraden seems to fear that soldiers lack the sophistication to appreciate Shakespeare while simultaneously hoping that she might be proved wrong.

To what extent did this reorientation of reported reading tastes in favour of the literary canon simply reflect the changing demographics of the British armed forces? ${ }^{18}$ Looking back on the conflict from the perspective of the 1930s, James Milne suggested that military reading habits over the course of the war could be sorted into three distinct and successive waves. The working-class 'Old Contemptibles' who had fought the first battles of the war had, he wrote, 'wanted reading of the humorous' and 'sensational $[\ldots]$ sort', while the more economically secure and culturally equipped territorials who later joined them at the front sought 'the better stuff to which civil life had accustomed them', and the 'massed everyman' placed in uniform by conscription read 'a mixture of the good, often the very good, and the merely distracting'. ${ }^{19}$ Contemporary observers made similar inferences about the cultural effects that the Kitchener and Derby Schemes, followed by the introduction of conscription, might have had upon Britain's armed forces. Writing in The Times Literary Supplement three months after the Military Service Act 1916 came into force, John Cann Bailey described 'the modern army' as 'a totally different thing from any we have had before. Both officers and men', he wrote, 'have been largely drawn from classes far more interested in books' than those who had entered the Army in the pre-war period. ${ }^{20}$ The movement of large sections of the middle-class male book-buying public into uniform, and their tendency to respond to the demands of service through the purchase of further books, could be measured in the new wartime sales patterns found in booksellers' statistics. While Bailey acknowledged that distinguishing the purchasing habits of civilian and military readers within aggregate data was difficult, he surmised that increased sales of astronomy books might represent demand from newly commissioned Royal Flying Corps pilots, while a run on Loeb editions 
suggested that classically educated soldiers were turning to Greek and Roman authors as recreational reading during their periods of service (Bailey, p. 253).

\section{The Uses of the Soldier-Reader}

The changing social composition of the British armed forces does not, however, entirely explain the new emphasis in press reports on soldiers' appetites for canonical literature. The image of the Shakespeare-reading soldier, given evidentiary weight by anecdotes of witnessed reading taking place in or around soldiers' libraries, was quickly made to serve a number of overlapping cultural, commercial, and propagandistic agendas. 1915 marked the year in which new charitable programmes for distributing reading material to the British armed forces began to reach critical mass. The Camps' Library was initially designed to stock libraries for Australian and New Zealand Army Corps (ANZAC) troops while in training on Salisbury Plain. ${ }^{21}$ Later extended to provide reading material for all British and Commonwealth soldiers, as well as British prisoners of war held behind enemy lines, the scheme advertised widely in the press for both monetary and book donations throughout 1915 and $1916 .^{22}$ Camps' Library publicity focussed on the scarcity of books at the front and the plight of soldiers faced with a lack of suitable recreational outlets. A Saturday Review article, written to highlight the outreach efforts of the Camps' Library, observed that the 'monotony of the life of our soldiers and sailors is a fact that every civilian should get firmly into his mind; for the soldiers depend almost entirely on the enterprise of people at home to break up and lighten this monotony'. ${ }^{23}$ Much of this public relations material relied on vivid anecdotes of individual soldier readers, often relayed by officers or chaplains in the field who took on the role of 'opinion leader' for home audiences. ${ }^{24}$ An April 1915 Camps' Library advertorial in The Times, for instance, quoted an anonymous officer who described the scene that unfolded when a box of Camps' Library books was unpacked for the men in his company. 'When I said I had a lot of books to lend', he was reported to have written, 'they were round me in moments like a lot of hounds at a worry, and in less than no time each had got a book, at least as far as they would go round [...] Can we have more?', he added, 'As many as you can spare'. ${ }^{25}$ 
The suggestion that soldiers were specifically requesting high status canonical literature became one of the major selling points of charitable book schemes' publicity campaigns. Profiling the work of the Edinburgh-based Soldiers' Recreation Fund in September 1917, The Scotsman focussed directly on the demand side of the exchange and what this suggested about the literary tastes of soldiers in Scottish regiments. 'Shakespeare and Byron are much in demand among the men at the front', it reported, along with 'poetry of the highest standard', the 'more serious and solid' weekly periodicals, and the 'biographies of famous men'. According to a spokesperson for the Fund interviewed for the article, 'soldiers never ask for anything but the best'. ${ }^{26}$ This emphasis on soldiers' apparent appetite for the canonical, and for Shakespeare in particular, is a common feature in wartime book charity publicity. Writing from France in November 1915, YMCA hut leader Walter Ashley reported that soldiers had borrowed a 'large number of Shakespeare's works' from his small lending library, alongside 'many books of poetry, theology and reference'. ${ }^{27}$ However, Ashley's account is also notable for what it reveals about why charities chose to foreground the Shakespeare-reading soldier in their publicity. When soliciting further donations for hut libraries, Ashley specified that the YMCA were in fact most in need of multiple copies of cheap reprint editions of classic Victorian novels by Charlotte Brontë, George Eliot, Wilkie Collins, and Charles Dickens-books which, as Jonathan Rose has suggested, had a relatively wide working-class readership in Britain in the period leading up to the First World War. ${ }^{28}$ If the Shakespeare-reading soldiers Ashley describes constitute in effect the 'display window' of this appeal, his list of requests indicates what the bulk of the demand in these YMCA hut libraries was likely to have been. Shakespeare, it turns out, forms the symbolic but not ultimately the material heart of this call for public donations.

The kinds of anecdotes about soldiers reading Shakespeare and other classic literature popular in charity appeals also segued over into the purely commercial side of book trade publicity. A display advertisement for the Times Book Club in 1916 began by relating stories of Homer's popularity among British soldiers at Gallipoli the previous year and the case of one soldier who, 'in the trenches, has for the first time in his life read Shakespeare steadily, play by play, and enjoyed it', before making its pitch for new subscriptions. ${ }^{29}$ In publicity notices like these, the cultural capital associated with Shakespeare travels in multiple directions. The thumbnail sketches of reading soldiers that these appeals and advertisements 
contain ostensibly memorialise the soldiers themselves, but Shakespeare's name also serves to venerate the charitable or commercial schemes that supply the texts, and ultimately the civilian donor or subscriber who provided the actual capital on which the schemes relied. At the same time, even though they were not official parts of the British propaganda apparatus, the publication of these sorts of accounts in large-circulation newspapers nevertheless contributed to what Peter Buitenhuis calls the 'paper curtain'-the sanitised, textual simulacrum of the war constructed in the press for home-front readers, which acted as a veil obscuring the underlying reality. ${ }^{30}$ The 'veiling' qualities of this material did not necessarily lie in untruth (there is no reason to think that eyewitness accounts of soldiers' libraries were broadly fabricated). Instead, as in much First World War British propaganda and war reporting, the effect lay in selecting the sorts of information relayed from the war zones, as well as attending carefully to the tone and emphases with which they were described. ${ }^{31}$ The focus on soldiers' 'recreations' and reading lives necessarily obscured other aspects of the military experience. Meanwhile, book charity publicity encouraged home-front audiences to see the plights of serving soldiers as philanthropic problems, which could be addressed by 'personal acts of moral service' in the form of charitable donations. ${ }^{32}$

For cultivated elites within the media and the book-trade, anecdotes of British soldiers reading the classics evidently provided a powerful source of psychological reassurance. ${ }^{33}$ In the early weeks of the conflict, a number of commentators had warned that the war would represent an existential threat to literature. ${ }^{34}$ Writing in September 1914, Edmund Gosse predicted that readers' attention would be entirely taken up by war news and current events for the duration of the conflict. 'The book which does not deal directly and crudely with the complexities of warfare and the various branches of strategy, will, from Christmas onwards, not be published at all', he wrote. ${ }^{35}$ After a sales peak in 1913, business in the British book-trade had been unusually slow in the months leading up to war's declaration, but Gosse warned, 'we can aspire to no revival'. This state of affairs would effectively place 'current literature' on hiatus until after the war (Gosse, p. 31). Book-trade commentators responded with relief when, in late 1914, sales figures indicated that the British reading public had not abandoned books and literature wholesale in favour of newspapers. 'Things are not going to be so bad as they were prophesied', Arthur Waugh predicted in The Fortnightly Review. 'For some inscrutable reason the book-trade is always peculiarly liable to panic'. 
Instead, he wrote, the British reading public had already started to put 'the daily papers' to one side and 'turn to the most satisfying of all intellectual consolations - the consolation of literature'. ${ }^{36}$ Echoing Waugh's tone of cautious optimism, The Book Monthly declared in October 1914 that 'there are already signs of a revival of interest in things literary', predicting that, under wartime conditions, 'recreative reading $[\ldots]$ will perhaps more than ever be enjoyed'. ${ }^{37}$

Claims that readers, both civilian and military, were returning to 'serious books' and 'older and worthier literature' were often accompanied by a specifically conservative aesthetic and cultural politics. ${ }^{38} \mathrm{~A}$ postscript to Gosse's article on 'War and Literature', added six months after its original publication, predicted the withering away of pre-war modernist and decadent tendencies in British literature. ${ }^{39}$ There would, he wrote, be 'a quiet persistence along the old paths' in both literary production and reception, and 'we may probably hear very little more about "vorticists" (Gosse, p. 38). Waugh declared that 'Decadence indeed is dead at the first assault', attributing the mood of pessimism in literary circles at the start of the war to the intellectually septic material upon the modern bookshelf', which had evidently 'infect[ed]' the 'blood' of booksellers (Waugh, pp. 771, 766).

These aesthetically conservative responses to the conflict were part of a wider critical turn. For an older generation of writers especially, the outbreak of war represented an opportunity to attack both modernism and aspects of contemporary commercial culture that disturbed them. The rejection of 'debased' or 'degenerate' aesthetic movements often involved a corresponding advocacy on behalf of more traditional literary and artistic forms. ${ }^{40}$ Addressing the Poetry Society in 1916, Herbert Warren encapsulated this sense of a collective return to the traditional canon when he said, 'I have lately, as I expect many of us have done, been reading Shakespeare again'. ${ }^{41}$ Cultural heritage, under the conditions of total war, became a powerful distillation of national identity, one that could be mobilised to further the war effort. ${ }^{42}$ If the conflict, as John Horne and Alan Kramer argue, became increasingly 'defined as a contest of values', then the literary values embedded in the canon became further ammunition in a war of culture against culture. As each side sought the mantle of 'culture' or 'civilisation' fighting against 'barbarism', the war became a contest for cultural as well as military superiority. ${ }^{43}$ 
Anecdotes of soldiers reading Shakespeare fitted within this wider context of cultural mobilisation. They also provided cultural commentators with a means of assuaging contemporary anxieties that, as the Athenaeum put it, 'the man in the street' preferred the 'live ass' of contemporary mass culture to the 'dead lion' of the literary past. ${ }^{44}$ The publicity surrounding the 1916 Shakespeare Tercentenary celebrations in Britain frequently acknowledged the fear that Britons had effectively forgotten Shakespeare, a fear exacerbated in the context of wartime by the suspicion that his name was venerated more widely outside of Britain than within it. ${ }^{45}$ The figure of the Shakespeare-reading soldier provided a corresponding sense of reassurance. It suggested that ordinary British readers still valued Shakespeare, preferring him in times of stress to the more apparently accessible attractions offered by contemporary commercial culture. By foregrounding the demand for literary classics in soldiers' libraries, book charity publicity made a similar set of representational claims. The military audiences in these press reports remember Shakespeare and therefore become worthy themselves of memorialisation. In doing so, they become signifiers of a sense of renewed cultural vitality engendered by war, as well as purported evidence that charities' attempts to lead soldiers to literature were bearing fruit.

\section{Soldiers, Shakespeare, and the Reading Nation}

In the decades leading up to the First World War, public library advocates in Britain increasingly came to describe the task of the librarian as one of moral and aesthetic cultivation. The library represented a site where working-class readers, through exposure to the 'best' books in the language, could be inducted into a shared English literary culture. Although YMCA hut libraries and charitable schemes like the War Library and the Camps' Library generally relied on the labour of temporary amateur volunteers rather than professional librarians, they adopted a similarly idealist rhetoric. Describing her wartime experiences providing books for wounded soldiers, War Library founder Helen Mary Gaskell claimed that, under her guidance, one patient had progressed from being a non-reader to being able to 'discuss [...] Sir Walter Scott and Robert Louis Stevenson's books with me as if he had written them'. ${ }^{47}$ Beatrice Harraden's account of wounded soldiers' reading practices indicates that she understood the role of hospital librarian in the same sorts of terms. 'My own impression', she wrote, 'is that [some soldiers] read rubbish 
because they have had no one to tell them what to read' (Harraden, p. 610). The hospital library, however, could provide the wounded with literary and cultural instruction. Although she claimed that none of the staff tried to 'force good books on our soldiers', she found that men would readily take to 'a better class of book' if it were 'put within their reach' (Harraden, p. 610). These reports depict libraries as part of a larger assortment of media and forms of popular recreation competing for soldiers' attention but suggest that books were nevertheless able to hold their own against the competition. In order to reach her small lending library situated at one end of a large hall, 'A Lady Librarian' writes, her soldier-customers had to successfully resist the temptations offered by an array of billiard tables, stalls selling tobacco and confectionery, and 'above all, the ceaseless ragtime strains of a cruelly overworked piano' ('A Lady Librarian', p. 6). Harraden depicted the relationship between mass culture and literary culture in less antagonistic terms, suggesting that certain mass-cultural artefacts could aid the formation of reading audiences. A soldier 'who seemed to us a most unpromising reader' asked for a copy of Much Ado About Nothing, having at some point seen a silent film version of the play, and afterwards 'several volumes of Shakespeare were taken to that bedside'. Reflecting on the route by which this soldier had arrived at Shakespeare, she concluded that 'the cinema has a great possibility of doing good as well as harm' (Harraden, p. 612). ${ }^{48}$

Reports like Harraden's represented hospital librarianship as a form of civic patriotism. By introducing soldiers to the English literary canon, volunteer librarians saw themselves as helping to create what David Monger calls a 'concrescent community', one that 'grow[s] together through $[\ldots]$ shared experiences' and comes to have a firm sense of its own collective national identity. ${ }^{49}$ Witnessed accounts of British military reading practices in the field likewise emphasised soldiers' willing participation in a shared, vigorous national culture. Both wartime journalism and charity publicity represented the reading communities that formed around soldiers' libraries and within units as idealised microcosms of national identity. ${ }^{50}$ In a dispatch from the Ypres sector published in Chambers's Journal in August 1917, Gordon Highlanders chaplain Lauchlan MacLean Watt took considerable pains to express both the diversity and quality of the reading tastes possessed by the men in the regiment. 'The infinite variety of classes that make up our present army is astonishing', he wrote. One Gordon Highlander had landed in France 'with a copy of the Hebrew Psalms in his khaki apron to read in 
the trenches', while Watt witnessed another man, 'an Aberdeen divinity student, as a private, reading in the mud the Greek Testament and the Sixth Book of Homer's Iliad'. Widening his descriptive field to encompass literary consumption habits among the Gordon Highlanders more generally, Watt recorded that 'Anything from [Homer] to the Daily Mail represents the reading of our men'. ${ }^{5}$ Found texts encountered in the trenches could also be incorporated within this wider narrative of literary democracy. One officer told Charles Hankinson that 'he picked up in one of the trenches near Ypres a copy of Sophocles in Greek [...] and within a few yards a copy of a popular threepenny sensational novelette', both books evidently 'well thumbed and $[\ldots]$ well read'. Underlining the point that these abandoned books epitomised the unprecedented degree of class mixing taking place in British units, Hankinson noted that the novelette 'emanated from a large firm of cheap literature providers', while the copy of Sophocles bore the imprint of 'one of the oldest publishing houses in London'. ${ }^{52}$ Soldiers' reading tastes thereby become a synecdoche for class positioning, their observed heterogeneity in the field contributing to the narrative of a unified 'nation in arms', in which members of all classes bore the burden of combat.

Soldiers' letters and diaries indicate that some did indeed carry editions of Shakespeare with them while on active service or read his works in hospital, although much of the evidence uncovered so far relates to officers rather than those in the ranks. ${ }^{53}$ One ordinary-ranking combatant who did so was Able Seaman Arthur Vernon of the Royal Naval Division, who was wounded during the Battle of Arras on 23 April 1917 and evacuated to hospital in England. On 8 May 1917, he wrote in his diary that he had received a parcel containing a collected edition of Shakespeare, alongside cigarettes, a writing pad, and a copy of Oliver Twist. The next day, he recorded reading $A$ Winter's Tale and Macbeth and, on 11 May 1917, Henry VIII. ${ }^{54}$ To judge by the sheer density of reading recorded in his diaries, which included multiple titles by Dickens and Sir Walter Scott, Vernon was a dedicated autodidact and a voracious reader whose literary consumption habits were already fully formed by the time he joined the war effort. Soldiers like Vernon were probably somewhat unrepresentative of the bulk of the armed forces. Generalisations about soldiers' reading habits, therefore, cannot be safely made from isolated examples such as this one.

A more comparative analysis of the reading practices of other ordinaryranking soldiers suggests that most were not as comfortable or familiar 
with 'high' literary culture as Able Seaman Vernon. Selective and idealised images of a diverse and cultivated 'reading nation' in the trenches, such as those provided by Lauchlan MacLean Watt and Charles Hankinson, therefore have to be approached with a good deal of interpretive caution. Aggregate examination of soldiers' written records suggests, and retail and production figures from the book-trade confirm, that the printed texts that circulated most widely among First World War British military reading audiences were newspapers and magazines, popular and middlebrow fiction (particularly in cheap reprint editions), Bibles and prayer books, and military instruction manuals and field service guides. ${ }^{55}$ Wilfully selective and partial eyewitness accounts of 'trench readers', with their exaggerated sense of the average British soldier's familiarity with the classical and English literary canons, nevertheless fulfilled their own sets of needs. The 'myth' of the Shakespeare-reading soldier served to retrospectively justify the efforts of book charities, while flattering the expectations of cultivated elites invested in the idea of moral and cultural improvement through the act of reading. ${ }^{56}$

The myth could also function as a form of 'adversarial patriotism', providing a counterweight to contemporary German claims on Shakespeare and other fixtures in the English literary canon. ${ }^{57}$ In 1915, The Birmingham Daily Post reported on an essay by the writer Arnold Höllriegel published earlier that year in the Berliner Tageblatt. Unwittingly mirroring some of the claims made in British book trade publicity, Höllriegel suggested that German soldiers were so fastidious about their reputations as readers that they made sure not to carry any 'trashy books' with them into battle. (This was to prevent potentially embarrassing titles being found on their corpses after they were killed.) These German soldier-readers, Höllriegel wrote, were especially fond of Dickens, and their assiduousness indicated to whom it was that the cultural legacy of the British literary canon really belonged:

Doubtless the English will claim this as evidence of the superiority of their literature. But let Tommy Atkins turn out his pockets and show whether it is copies of Dickens or sixpenny dreadfuls they contain. After all, it is a question to which nation Dickens really belongs. In Shakespeare's case, we have long since decided it in our favour. ${ }^{58}$

Battlefield literary intelligence as relayed by the newspaper anecdote could act as counters to these kinds of challenges to British national literary 
taste. The anecdote of the reading soldier was also capable of performing more localised acts of patriotic memorialisation. Watt's prose portraits of soldier-readers were implicit tributes to the literary culture of the Gordon Highlanders' home base, Aberdeen, and, as mention of the 'Aberdeen divinity student' reading Greek makes clear, to the University of Aberdeen more specifically. ${ }^{59}$ Soldiers themselves could be enthusiastic participants in these acts of national literary chauvinism. Writing to his father in 1915 about taking a copy of the Odyssey into battle, one Scottish junior officer claimed, 'that is my Scots blood coming out. Only a Scotsman would take his classics to the front'. ${ }^{60}$ As many British newspapers encouraged their readers to do, his parents then forwarded on the letter for print publication. By the time the letter ultimately appeared in The Scotsman, it had accrued multiple layers of memorialisation. It served to commemorate a specifically Scottish reading culture and identity while also paying tribute to the soldier himself and his family group.

\section{CONCLUSION: REMEMBERING The Shakespeare-Reading Soldier}

On 23 April 1919, on the 355th anniversary of Shakespeare's birth, The Times published a long reminiscence from 'A Correspondent', which purported to describe the frontline soldier's relationship with Shakespeare. At first, he wrote, 'the study of Shakespeare in the field was chiefly the renewal of an old love', undertaken singly by 'intellectual' soldiers using cheap collected editions they had brought with them from home. As the war went on, however, Shakespeare became the common property of whole sections, who read him with an intensity that would have been unreproducible under peacetime conditions. 'A Correspondent' gave the example of one detachment who 'found their supreme relaxation' in shared readings of a single edition of Hamlet:

They were far forward, often (for their job was intelligence) within the enemy's lines, their lives not worth a minute's purchase. Listening $[\ldots]$ with strained ears for the foe 'delving a yard beneath their mines' $[\ldots]$ they found $[\ldots]$ relief, when relief came, in the tale of Elsinore. The dug-out swarmed with rats, spry and ill to slay, but for every lucky hit the universal Dane had his appropriate word. 'Lie there, poor rat', gave a touch of droll incongruity to victory over the rodent, and lightened the heavy hour. In that water-logged hovel, on sleepless nights, the coterie gathered round a 
guttering dip and forgot the weariness and the wet; now reading for pure joy of the verse, now debating the eternal riddle of the play. ${ }^{61}$

Echoing the 'adversarial' literary patriotism of wartime publicity, 'A Correspondent' describes how one of the men then happened upon an abandoned copy of Goethe's Faust in a German trench. Repelled by the 'obvious crudity' of the work, he wrote, no one in the unit was 'tempted to play tit-for-tat with the Hun, and claim Goethe for an Englishman' ('Shakespeare and Modern Soldiers', p. 16). With, perhaps, a certain degree of playfulness, this post-war Times article managed to incorporate within its brief word count many of the tropes associated with wartime anecdotes of Shakespeare-reading soldiers. It positions Shakespeare in relation to rival national literatures, while also portraying war experience itself in explicitly literary terms. Drawing on the tradition of parodic literary criticism in British trench journals, it lets 'drolly' re-contextualised Shakespeare quotes stand in for the absurdities and horrors of the trench existence. ${ }^{62}$

There is some evidence of wartime witnesses fighting back against this kind of retrospective literary-memorialisation of their war experience. After reading a newspaper report stating that the Rubáiyát of Omar Khayyám and the Bible had been the two most popular books with First World War British soldiers, one ex-serviceman wrote to the paper that he had been 'in the Army from September 1914, to March 1919' and 'did not at any time see a copy of Omar Khayyam being read by a soldier', while the only Bibles he remembered had been in the hands of chaplains during Sunday services. ${ }^{63}$ Regardless of occasional attempts like this one to set the record straight, the circulation of anecdotes like that printed by The Times on 23 April 1919 may have contributed to what Kate McLoughlin calls 'an over-estimation of the literariness' of the ordinary British soldier in post-war memory. ${ }^{64}$ Idealised representations of 'high-brow' wartime readers, created for the purposes of propaganda and publicity, ultimately came to stand in for actual soldier-readers (who generally preferred newspapers, magazines, and popular fiction). This was part of a larger set of cultural processes that foregrounded the literary side of the war, one that unfolded over decades. School curricula in Britain and other Anglophone nations encouraged generations of students to approach the conflict through the writings of a small 'honour guard' of war poets. ${ }^{65}$ Post-war patterns in the publishing industry, particularly the 'war books boom' of 1928-30, likewise elevated the voices of literary 
minded memoirists such as Edmund Blunden and Siegfried Sassoonwho both stuffed their accounts with records of high-brow wartime reading-over those of less articulate and artful witnesses. These developments helped to generate a version of the war in which literature and war experience were intimately entwined, one that arguably culminated in Paul Fussell's Great War and Modern Memory (1975), with its overt and highly influential depiction of 'a literary war'. ${ }^{66}$ Wartime publicity accounts of the trench reader anticipate some of these developments, demonstrating how the cultural mobilisation of the serving soldier functioned during the conflict itself, while perhaps also helping to lay the groundwork for the literary memorialisation of the war that was to come.

Despite their questionable status as evidence about soldiers' actual literary tastes, wartime anecdotes about soldiers reading Shakespeare and other classics can be read as discourses in their own right. ${ }^{67}$ Asking what impelled correspondents to record these anecdotes and how and why they were circulated can help to reveal the aspirations and anxieties that underlay voluntary efforts to spread the reading habit among soldiers, as well as the assumptions involved about the function of reading in war zones. The 'myth' of the soldier-reader that charity and booktrade publicity created for home audiences placed consumption of the literary canon front and centre. Not only do these anecdotes effectively elide other, less culturally elevated forms of soldierly behaviour from view, instead positioning 'reading [as] the soldier's chief recreation', but they also exclude other genres and forms of popular reading material. ${ }^{68}$ If, as wartime rhetoric claimed, the massed volunteerism of 1914 had led to Britain's armed forces becoming something like 'the nation itself', rather than (as before the war) a socioeconomically unrepresentative subsection of it, book charity publicity represented that collective specifically as a reading nation, one that was growing confidently into possession of its literary and artistic heritage. ${ }^{69}$ In doing so, it performed an act of cultural mobilisation, effectively converting the reading soldier into a symbol of idealised Anglophone and British culture.

In accordance with long-standing assumptions about the improving powers of literature, the soldier-readers represented in these accounts move along a specific trajectory. They undertake a journey towards Shakespeare and other canonical authors. Describing the military reader's 'upward climb' towards acquiring literary taste in The Fortnightly Review in 1919, James Milne gave an account of one 40-year-old private who was lent a copy of Thomas Hardy's Under the Greenwood Tree by a unit 
comrade, a bookseller in civilian life. He read it in fits and starts, and when he finished, declared that, 'I've read hundreds of "bloods," but this yarn is the real thing'. It was through mediated discoveries like this, Milne wrote, that the 'soldier-reader' was created. 'When found, Shakespeare's Hamlet is not beyond him, and he will assail Swinburne and Yeats, and not be shy of Erewhon' ${ }^{70}$ The lecture that Beatrice Harraden gave to the National Home Reading Union, on which her later Cornhill Magazine article was based, concluded similarly by following the developing reading tastes of one of her patients during his convalescence. Allowed to borrow books from the library as an outpatient, Harraden remembered him asking her for advice on what authors he should read next. 'He was', she said, 'one of those who had progressed from that mysterious weekly, "The Union Jack", to Dumas', and she firmly believed that 'he would end with Shakespeare'. ${ }^{71}$

\section{Notes}

1. Sidney Lee, 'Drama for Soldiers: To the Editor of the Times', The Times, 30 October 1916, p. 9.

2. Sidney Lee, The Place of English Literature in the Modern University (London: Smith, Elder \& Co., 1913), pp. 20; 22.

3. On Shakespeare's place in the British Red Cross and Order of St John War Library, see Reports by the Joint War Committee and the Joint War Finance Committee of the British Red Cross Society: Voluntary Aid Rendered to the Sick and Wounded at Home and Abroad and to British Prisoners of War, 1914-1919 (London: HMSO, 1919), p. 271.

4. For contemporary commentary on Shakespeare and national ideals, see Ernest de Sélincourt, English Poets and the National Ideal: Four Lectures (London: Oxford University Press, 1915), pp. 8; 20; 24-25 and H. C. Beeching, 'Shakespeare and the English Ideal', Norwich Public Library Readers' Guide, 5.3 (June 1916), 58-69 (p. 58).

5. See Vincent Trott, Publishers, Readers and the Great War: Literature and Memory Since 1918 (London: Bloomsbury, 2017), p. 1.

6. 'Letters from the Front', The Spectator, 19 September 1914, pp. 389-390 (p. 390). 
7. James Milne, 'A London Letter: The Epistles of Thomas Atkins as Literature', The Book Monthly (December 1914), 166-69 (p. 166). See The War Stories of Private Thomas Atkins, ed. by James Milne (London: George Newnes, 1914), p. 135, for the reference to a soldier reading Ruskin. This volume was a sequel to Milne's earlier collection of excerpts from British soldiers' letters written during the South African War, The Epistles of Atkins, ed. by James Milne (London: T. Fisher Unwin, 1902).

8. On official attitudes to the reading habits of soldiers in the pre-war British regular army, see Sharon Murphy, "Quite Incapable of Appreciating Books Written for Educated Readers": The Mid-Nineteenth-Century British Soldier', in A Return to the Common Reader: Print Culture and the Novel, 1850-1900, ed. by Beth Palmer and Adelene Buckland (Aldershot: Ashgate, 2011), pp. 121-132.

9. 'A Lady Librarian', 'What the New Army Reads', Daily Chronicle, 9 February 1915 , p. 6.

10. 'Soldiers and Reading', Edinburgh Evening News, 10 February 1915 , p. 4.

11. See Christopher Hilliard, 'Popular Reading and Social Investigation in Britain, 1850s-1940s', Historical Journal, 57.1 (2014), 247-271.

12. Wilkie Collins, 'The Unknown Public', Household Words, 439 (21 August 1858), 217-222 (p. 222).

13. 'The Companionship of the Pen', The Spectator, 17 October 1914, pp. 520-521 (p. 520).

14. 'Soldiers' Stories', Aberdeen Evening Press, 21 January 1915, p. 2.

15. 'Life and Letters', The Academy, 31 July 1915, pp. 67-69 (p. 68).

16. 'The War and Reading', Arbroath Herald and Advertiser, 27 April 1917 , p. 4.

17. Beatrice Harraden, 'What Our Soldiers Read', Cornhill Magazine (November 1916), pp. 607-613 (pp. 608; 611). This article was based on a lecture Harraden gave to the National Home Reading Union on 4 January 1916: see 'What Soldiers Read: Great Demand for Nat Gould's Novels', Manchester Guardian, 5 January 1916, p. 3. In what follows, I have reconstructed its contents from several different press reports of the original lecture. On Harraden's activities in setting up the Endell Street Hospital library, see Wendy Moore, Endell Street: The Trailblazing Women Who Ran World 
War One's Most Remarkable Hospital (London: Atlantic, 2020), 108-111.

18. On the class composition of the pre-war British Regular Army, see Edward M. Spiers, 'The Regular Army', in A Nation in Arms: A Social Study of the British Army in the First World War, ed. by Ian F. W. Beckett and Keith Simpson (1985; Barnsley: Pen \& Sword, 2004), pp. 37-61 (pp. 44; 46). On class dynamics in the New Armies, see J. M. Winter, 'Britain's "Lost Generation" of the First World War', Population Studies, 31.3 (1977), 449-66 (pp. 452$56)$.

19. James Milne, The Memoirs of a Bookman (London: John Murray, 1934), p. 281.

20. John Cann Bailey, 'Literature and the War', Times Literary Supplement, 1 June 1916, pp. 253-254 (p. 253).

21. Theodore Wesley Koch, Books in Camp, Trench and Hospital (London: J. M. Dent, 1917), pp. 18-19.

22. On the Camps' Library and its operations, see Edmund G. C. King, "Books Are More to Me than Food": British Prisoners of War as Readers, 1914-1918', Book History, 16 (2013), 247-271 (pp. 251-253) and Peter Grant, Philanthropy and Voluntary Action in the First World War: Mobilizing Charity (Abingdon: Routledge, 2014), pp. 129-131.

23. 'The Monotony of War', The Saturday Review, 11 September 1915 , p. 246.

24. On soldiers as willing contributors to British wartime publicity and propaganda, see David Monger, 'Soldiers, Propaganda and Ideas of Home and Community in First World War Britain', Cultural and Social History, 8.3 (2011), 331-354 (pp. 346-349).

25. 'Soldiers' Reading: Books Needed for the Trenches', The Times, 2 April 1915, p. 3.

26. 'Shakespeare in the Trenches: High Standard of Soldiers' Literature', The Scotsman, 27 September 1917, p. 6.

27. 'Books Read by Soldiers: The Kind of Library Required', Newcastle Journal, 26 November 1915, p. 4.

28. For the popularity of cheap reprint series among military readers during the war, see Imogen Gassert, 'In a Foreign Field: What Soldiers in the Trenches Liked to Read', Times Literary Supplement, 10 May 2002, pp. 17-19, and Shafquat Towheed and Edmund G. C. King, 'Introduction', in Reading and the First 
World War: Readers, Texts, Archives, ed. by Shafquat Towheed and Edmund G. C. King (Basingstoke: Palgrave Macmillan, 2015), pp. 1-25 (pp. 6-8). For the enduring popularity of Dickens and other Victorian novelists among working-class British readers, see Jonathan Rose, 'A Conservative Canon: Cultural Lag in British Working-Class Reading Habits', Libraries and Culture, 33.1 (1998), 98-104. For their readerships in the wartime British Army, see Edmund G. C. King, 'E. W. Hornung's Unpublished "Diary," the YMCA, and the Reading Soldier during the First World War', English Literature in Transition, 1880-1920, 57.3 (2014), 361-387 (pp. 372; 376-378) and Marcella P. Sutcliffe, 'Reading at the Front: Books and Soldiers in the First World War', Paedagogica Historica, 52.1-2 (2016), 104-120 (pp. 105-106).

29. 'Books: A Parable', The Times, 25 September 1916, p. 14.

30. Peter Buitenhuis, The Great War of Words: Literature and Propaganda 1914-18 and After (London: B. T. Batsford, 1989), pp. 79; 90. On the nature of First World War press reporting, see also Stéphane Audoin-Rouzeau, Men at War 1914-1918: National Sentiment and Trench Journalism in France during the First World War, translated by Helen McPhail (Oxford: Berg, 1992), pp. 92-109, and Randall Stevenson, Literature and the Great War, 1914-1918 (Oxford: Oxford University Press, 2013), pp. 23-28.

31. Philip M. Taylor, British Propaganda in the Twentieth Century: Selling Democracy (Edinburgh: Edinburgh University Press, 1999), p. 45.

32. Rebecca Gill, Calculating Compassion: Humanity and Relief in War, Britain 1870-1914 (Manchester: Manchester University Press, 2013), p. 213.

33. On 'cultivated elites', see D. L. LeMahieu, A Culture for Democracy: Mass Communication and the Cultivated Mind in Britain Between the Wars (Oxford: Clarendon Press, 1988), pp. 103-107.

34. See Jane Potter, 'The British Publishing Industry and the First World War', in The Edinburgh Companion to the First World War and the Arts, ed. by Ann-Marie Einhaus and Katherine Isobel Baxter (Edinburgh: Edinburgh University Press, 2017), pp. 371384 (pp. 373-375).

35. Edmund Gosse, Inter Arma: Being Essays Written in Time of War (London: Heinemann, 1916), p. 31. On the sales conditions in the British book-trade leading up to the start of the war, see James 
Milne, 'A London Letter: A Summer of Discontent in the Book Market', The Book Monthly (July 1914), 705-709.

36. Arthur Waugh, 'Literature and the War', The Fortnightly Review (November 1914), 766-73 (pp. 766; 770).

37. C. E. Lawrence, 'Novels With a Cry: A Glance at Six of the Season's New Stories', The Book Monthly (October 1914), 84-88 (p. 84).

38. 'The Revival of Leisure for Literature', Publishers' Circular, 12 August 1916, p. 147.

39. For discussions of Gosse's arguments, see Buitenhuis, pp. 51-53, and Samuel Hynes, A War Imagined: The First World War and English Culture (London: Pimlico, 1992), pp. 12-14.

40. See Hynes, A War Imagined, p. 64; Paul Peppis, "Surrounded by a Multitude of Other Blasts": Vorticism and the Great War', Modernism/Modernity, 4.2 (1997), 39-63 (p. 44); James Fox, "“Fiddling While Rome is Burning": Hostility to Art During the First World War, 1914-18', Visual Culture in Britain, 11.1 (2010), 49-65; and George Robb, British Culture and the First World War, 2nd edn (Basingstoke: Palgrave Macmillan, 2015), p. 156.

41. Herbert Warren, 'The Appeal of Poetry at the Present Hour', The Fortnightly Review (July 1916), 110-23 (p. 122).

42. See John Horne, 'Introduction: Mobilizing for "Total War", 1914-1918', in State, Society and Mobilization in Europe during the First World War, ed. by John Horne (Cambridge: Cambridge University Press, 1997), pp. 1-17 (pp. 1-2). On Shakespeare and cultural mobilisation, see Matthew C. Hendley, 'Cultural Mobilization and British Responses to Cultural Transfer in Total War: The Shakespeare Tercentenary of 1916', First World War Studies, 3.1 (2012), 25-49 (pp. 27-30) and Monika Smialkowska, 'Introduction: Mobilizing Shakespeare During the Great War', Shakespeare, 10.3 (2014), 225-9 (pp. 225-227).

43. John Horne and Alan Kramer, German Atrocities, 1914: A History of Denial (New Haven: Yale University Press, 2001), pp. 278-9; Alan Kramer, Dynamic of Destruction: Culture and Mass Killing in the First World War (Oxford: Oxford University Press, 2009), pp. 180-183.

44. 'The Shakespeare Celebrations', The Athenaeum, 4605 (May 1916), 220. For other contemporary press articles that comment 
on Shakespeare's declining readerships in the early twentieth century, see Andrew Lang and 'X', A Working Man, 'The Reading Public', Cornhill Magazine (December 1901), pp. 78395 (pp. 789; 794-5); Alfred Berlyn, "“Culture" for the Million', The Academy, 4 October 1913, pp. 421-422 (p. 422); and Thomas Seccombe, 'Our Shakespeare', The Bookman (April 1916), 7-15 (p. 10). For a wider historical survey of working-class audiences for Shakespeare in the late nineteenth and early twentieth centuries, see Andrew Murphy, Shakespeare for the People: WorkingClass Readers, 1800-1900 (Cambridge: Cambridge University Press, 2008), pp. 162-186.

45. See Ailsa Grant Ferguson, "When Wasteful War Shall Statues Overturn": Forgetting the Shakespeare Hut', Shakespeare, 10.3 (2014), 276-292 (p. 278).

46. See Alistair Black, A New History of the English Public Library: Social and Intellectual Contexts, 1850-1914 (London: Leicester University Press, 1996), pp. 165-166.

47. Helen Mary Gaskell, 'Hospital Libraries Past and Present', The Book Trolley, 1.10 (1937), 203-207 (p. 207). On Gaskell's role in kick-starting the provision of books for wounded and sick soldiers through her foundation of the War Library, see Sara Haslam, 'Reading, Trauma and Literary Caregiving, 1914-1918: Helen Mary Gaskell and the War Library', Journal of Medical Humanities, 41.3 (2020), 305-321.

48. Harraden's soldier-patient may have seen either Phillips Smalley's 1913 short version of Much Ado About Nothing or a 1913 Cricks and Martin short entitled Much Ado About. Neither film would have been likely to convey much of the play's plot. See Robert Ball, Shakespeare on Silent Film: A Strange Eventful History (London: Allen \& Unwin, 1968), p. 163.

49. David Monger, Patriotism and Propaganda in First World War Britain: The National War Aims Committee and Civilian Morale (Liverpool: Liverpool University Press, 2012), p. 93.

50. Cf. Andrew Frayn, Writing Disenchantment: British First War Prose, 1914-30 (Manchester: Manchester University Press, 2014), pp. $45-46$.

51. Lauchlan MacLean Watt, 'In the Salient: III', Chambers's Journal (18 August 1917), pp. 601-605 (p. 602). 
52. Clive Holland [Charles James Hankinson], 'The Romance and Pathos of Trench and Hospital Libraries', Chambers's Journal (4 November 1916), pp. 781-784 (p. 782).

53. Edmund G. C. King, " A Priceless Book to Have Out Here": Soldiers Reading Shakespeare in the First World War', Shakespeare, 10.3 (2014), 230-244.

54. Able Seaman Arthur Vernon, 1917 Diary, entries for 23 April and 8, 9, and 11 May 1917, Private Papers of A. Vernon, Imperial War Museum, London, Documents.16922. It is unclear if the date of his wounding had anything to do with Vernon's choice to read Shakespeare, but the coincidence is nevertheless striking.

55. Jane Potter, Boys in Khaki, Girls in Print: Women's Literary Responses to the Great War 1914-1918 (Oxford: Clarendon Press, 2005), pp. 52-55; 89-90; Jane Potter, 'For Country, Conscience and Commerce: Publishers and Publishing, 19141918', in Publishing in the First World War: Essays in Book History, ed. by Mary Hammond and Shafquat Towheed (Basingstoke: Palgrave Macmillan, 2007), pp. 11-26 (p. 12); Lise Jaillant, 'Sapper, Hodder \& Stoughton, and the Popular Literature of the Great War', Book History, 14 (2011), 137-66 (p. 138); Towheed and King, 'Introduction', pp. 7-11; and Owen Davies, A Supernatural War: Magic, Divination, and Faith During the First World War (Oxford: Oxford University Press, 2018), pp. 179-180.

56. Cf. Kathryne A. Bevilacqua, 'Making U. S. Readers in the Early Twentieth Century', PhD diss., University of Michigan, 2016, pp. 233-234.

57. See Monger, Patriotism and Propaganda, pp. 91-92. On German rhetorical claims to ownership of Shakespeare, see Balz Engler, 'Shakespeare in the Trenches', Shakespeare Survey, 44 (1991), 105111 (p. 109); Werner Habicht, 'Shakespeare Celebrations in Time of War', Shakespeare Quarterly, 52.4 (2001), 441-455 (pp. 452453); and Clara Calvo, 'Fighting over Shakespeare: Commemorating the 1916 Tercentenary in Wartime', Critical Survey, 24.3 (2012), 48-72 (pp. 53-55).

58. 'German Press Echoes', Birmingham Daily Post, 27 April 1915, p. 6. Parts of this article were excerpted as 'The Nationality of Dickens: Another Impudent German Claim', The Dickensian, 11.6 (June 1915), 161. 
59. On Scottish commentators' attempts to commemorate their own 'localities' via an appropriation of Shakespeare's 'cultural prestige' during the conflict, see Emily C. Anderson, 'The 1916 Shakespeare Tercentenary in Scotland: Concepts of Nation-ness and Cultural Prestige in Anniversary Tributes to the Playwright', Shakespeare, 12.2 (2016), 185-210 (pp. 189-90).

60. 'Some Trench Scenes: A Subaltern's Letters', The Scotsman, 11 September 1915 , p. 11.

61. 'Shakespeare and Modern Soldiers: Experiences in France', The Times, 23 April 1919, p. 16.

62. On the parodic mode in British soldiers' journals, see Graham Seal, The Soldiers' Press: Trench Journals in the First World War (Basingstoke: Palgrave Macmillan, 2013), pp. 33-35; 40-42.

63. 'Woodseats', 'What Soldiers Read', Sheffield Daily Independent, 28 October 1933 , p. 6 . The offending article was a brief paragraph printed in the paper the previous day, reporting on a lecture by W. A. Kirkby to the Sheffield Literary Club on 26 October 1933.

64. Kate McLoughlin, 'The Great War and Modern Memory', Essays in Criticism, 64.4 (2014), 436-458 (p. 440).

65. Alisa Miller, 'Towards a Popular Canon: Education, Young Readers and Authorial Identity in Great Britain between the Wars', in Towheed and King, eds, Reading and the First World War, pp. 45-60 (p. 55).

66. See Brian Bond, The Unquiet Western Front: Britain's Role in Literature and History (Cambridge: Cambridge University Press, 2002), pp. 39-40; Dan Todman, The Great War: Myth and Memory (London: Hambledon Continuum, 2005), pp. 155-161; Frayn, pp. 4-5; and Ian Beckett, Timothy Bowman, and Mark Connelly, The British Army and the First World War (Cambridge: Cambridge University Press, 2017), p. 135.

67. See Daniel Allington and Joan Swann, 'The Mediation of Response: A Critical Approach to Individual and Group Reading Practices', in The History of Reading, Volume 3: Methods, Strategies, Tactics, ed. by Rosalind Crone and Shafquat Towheed (Basingstoke: Palgrave Macmillan, 2011), pp. 80-96 (pp. 81-83).

68. For this wording, see 'Books and Authors', Sunday School Chronicle and Christian Outlook, 25 May 1916, p. 336.

69. Cf. J. H. Grainger, Patriotisms: Britain 1900-1939 (London: Routledge \& Kegan Paul, 1986), p. 308. 
70. James Milne, 'The Soldier as a Reader', The Fortnightly Review (May 1919), 752-759 (pp. 757-758).

71. 'Soldiers' Books: The Chief Desires of the Wounded', Falkirk Herald, 12 January 1916, p. 4. The Union Jack was a boys' weekly story paper founded by Alfred Harmsworth (later Lord Northcliffe) in 1894. It was well known for its imperialistic and anti-German themes. See Dennis Butts, 'Shaping Boyhood: British Empire Builders and Adventurers', in The International Companion Encyclopedia of Children's Literature, ed. by Peter Hunt (Abingdon: Routledge, 2004), pp. 340-351 (p. 343).

\section{REFERENCES}

Allington, Daniel and Joan Swann, 'The Mediation of Response: A Critical Approach to Individual and Group Reading Practices', in The History of Reading, Volume 3: Methods, Strategies, Tactics, ed. by Rosalind Crone and Shafquat Towheed (Basingstoke: Palgrave Macmillan, 2011), pp. 80-96

Anderson, Emily C., 'The 1916 Shakespeare Tercentenary in Scotland: Concepts of Nation-ness and Cultural Prestige in Anniversary Tributes to the Playwright', Shakespeare, 12.2 (2016), 185-210

Audoin-Rouzeau, Stéphane, Men at War 1914-1918: National Sentiment and Trench Journalism in France during the First World War, translated by Helen McPhail (Oxford: Berg, 1992)

Bailey, John Cann, 'Literature and the War', Times Literary Supplement, 1 June 1916, pp. 253-254

Ball, Robert, Shakespeare on Silent Film: A Strange Eventful History (London: Allen \& Unwin, 1968)

Beckett, Ian, Timothy Bowman, and Mark Connelly, The British Army and the First World War (Cambridge: Cambridge University Press, 2017)

Beeching, H. C., 'Shakespeare and the English Ideal', Norwich Public Library Readers' Guide, 5.3 (June 1916), 58-69

Berlyn, Alfred, "“Culture" for the Million', The Academy, 4 October 1913, pp. $421-422$

Bevilacqua, Kathryne A., 'Making U. S. Readers in the Early Twentieth Century', $\mathrm{PhD}$ diss., University of Michigan, 2016

Black, Alistair, A New History of the English Public Library: Social and Intellectual Contexts, 1850-1914 (London: Leicester University Press, 1996)

Bond, Brian, The Unquiet Western Front: Britain's Role in Literature and History (Cambridge: Cambridge University Press, 2002)

'Books and Authors', Sunday School Chronicle and Christian Outlook, 25 May 1916 , p. 336 
'Books: A Parable', The Times, 25 September 1916, p. 14

'Books Read by Soldiers: The Kind of Library Required', Newcastle Journal, 26 November 1915, p. 4

Buitenhuis, Peter, The Great War of Words: Literature and Propaganda 1914-18 and After (London: B. T. Batsford, 1989)

Butts, Dennis, 'Shaping Boyhood: British Empire Builders and Adventurers', in The International Companion Encyclopedia of Children's Literature, ed. by Peter Hunt (Abingdon: Routledge, 2004), pp. 340-351

Calvo, Clara, 'Fighting over Shakespeare: Commemorating the 1916 Tercentenary in Wartime', Critical Survey, 24.3 (2012), 48-72

Collins, Wilkie, 'The Unknown Public', Household Words, 439 (21 August 1858), 217-222

'The Companionship of the Pen', The Spectator, 17 October 1914, pp. 520-521

Davies, Owen, A Supernatural War: Magic, Divination, and Faith During the First World War (Oxford: Oxford University Press, 2018)

de Sélincourt, Ernest, English Poets and the National Ideal: Four Lectures (London: Oxford University Press, 1915)

Engler, Balz, 'Shakespeare in the Trenches', Shakespeare Survey, 44 (1991), 105111

Ferguson, Ailsa Grant, "WWhen Wasteful War Shall Statues Overturn”: Forgetting the Shakespeare Hut', Shakespeare, 10.3 (2014), 276-292

Fox, James, "Fiddling While Rome is Burning": Hostility to Art During the First World War, 1914-18', Visual Culture in Britain, 11.1 (2010), 49-65

Frayn, Andrew, Writing Disenchantment: British First War Prose, 1914-30 (Manchester: Manchester University Press, 2014)

Fussell, Paul, The Great War and Modern Memory (Oxford: Oxford University Press, 1975)

Gaskell, Helen Mary, 'Hospital Libraries Past and Present', The Book Trolley, 1.10 (1937), 203-207

Gassert, Imogen, 'In a Foreign Field: What Soldiers in the Trenches Liked to Read', Times Literary Supplement, 10 May 2002, pp. 17-19

'German Press Echoes', Birmingham Daily Post, 27 April 1915, p. 6

Gill, Rebecca, Calculating Compassion: Humanity and Relief in War, Britain 1870-1914 (Manchester: Manchester University Press, 2013)

Gosse, Edmund, Inter Arma: Being Essays Written in Time of War (London: Heinemann, 1916)

Grainger, J. H., Patriotisms: Britain 1900-1939 (London: Routledge \& Kegan Paul, 1986)

Grant, Peter, Philanthropy and Voluntary Action in the First World War: Mobilizing Charity (Abingdon: Routledge, 2014)

Habicht, Werner, 'Shakespeare Celebrations in Time of War', Shakespeare Quarterly, 52.4 (2001), 441-455

Harraden, Beatrice, 'What Our Soldiers Read', Cornhill Magazine (November 1916), pp. 607-613 
Haslam, Sara, 'Reading, Trauma and Literary Caregiving, 1914-1918: Helen Mary Gaskell and the War Library', Journal of Medical Humanities, 41.3 (2020), 305-321

Hendley, Matthew C., 'Cultural Mobilization and British Responses to Cultural Transfer in Total War: The Shakespeare Tercentenary of 1916', First World War Studies, 3.1 (2012), 25-49

Hilliard, Christopher, 'Popular Reading and Social Investigation in Britain, 1850s-1940s', Historical Journal, 57.1 (2014), 247-271

Holland, Clive [Charles James Hankinson], 'The Romance and Pathos of Trench and Hospital Libraries', Chambers's Journal (4 November 1916), pp. 781784

Horne, John, 'Introduction: Mobilizing for "Total War", 1914-1918', in State, Society and Mobilization in Europe during the First World War, ed. by John Horne (Cambridge: Cambridge University Press, 1997), pp. 1-17

— and Alan Kramer, German Atrocities, 1914: A History of Denial (New Haven: Yale University Press, 2001)

Hynes, Samuel, A War Imagined: The First World War and English Culture (London: Pimlico, 1992)

Jaillant, Lise, 'Sapper, Hodder \& Stoughton, and the Popular Literature of the Great War', Book History, 14 (2011), 137-166

King, Edmund G. C., "“A Priceless Book to Have Out Here”: Soldiers Reading Shakespeare in the First World War', Shakespeare, 10.3 (2014), 230-244

— 'E. W. Hornung's Unpublished 'Diary', the YMCA, and the Reading Soldier during the First World War', English Literature in Transition, 18801920, 57.3 (2014), 361-387

— , "Books Are More to Me than Food": British Prisoners of War as Readers, 1914-1918', Book History, 16 (2013), 247-271

Koch, Theodore Wesley, Books in Camp, Trench and Hospital (London: J. M. Dent, 1917)

Kramer, Alan, Dynamic of Destruction: Culture and Mass Killing in the First World War (Oxford: Oxford University Press, 2009)

'A Lady Librarian', 'What the New Army Reads', Daily Chronicle, 9 February 1915 , p. 6

Lang, Andrew and 'X', A Working Man, 'The Reading Public', Cornhill Magazine (December 1901), pp. 783-795

Lawrence, C. E., 'Novels With a Cry: A Glance at Six of the Season's New Stories', The Book Monthly (October 1914), 84-88

Lee, Sidney, 'Drama for Soldiers: To the Editor of the Times', The Times, 30 October 1916, p. 9

- The Place of English Literature in the Modern University (London: Smith, Elder \& Co., 1913)

LeMahieu, D. L., A Culture for Democracy: Mass Communication and the Cultivated Mind in Britain Between the Wars (Oxford: Clarendon Press, 1988) 
'Letters from the Front', The Spectator, 19 September 1914, pp. 389-390

'Life and Letters', The Academy, 31 July 1915, pp. 67-69

McLoughlin, Kate, 'The Great War and Modern Memory', Essays in Criticism, 64.4 (2014), 436-458

Miller, Alisa, 'Towards a Popular Canon: Education, Young Readers and Authorial Identity in Great Britain between the Wars', in Shafquat Towheed and Edmund G. C. King, eds., Reading and the First World War: Readers, Texts, Archives (Basingstoke: Palgrave Macmillan, 2015), pp. 45-60

Milne, James, 'A London Letter: The Epistles of Thomas Atkins as Literature', The Book Monthly, 12.4 (December 1914), 166-169

- 'A London Letter: A Summer of Discontent in the Book Market', The Book Monthly (July 1914), 705-709

— The Memoirs of a Bookman (London: John Murray, 1934)

— - 'The Soldier as a Reader', The Fortnightly Review (May 1919), 752-9

— ed., The Epistles of Atkins (London: T. Fisher Unwin, 1902)

- ed., The War Stories of Private Thomas Atkins (London: George Newnes, 1914)

Monger, David, Patriotism and Propaganda in First World War Britain: The National War Aims Committee and Civilian Morale (Liverpool: Liverpool University Press, 2012)

— 'Soldiers, Propaganda and Ideas of Home and Community in First World War Britain', Cultural and Social History, 8.3 (2011), 331-354

'The Monotony of War', The Saturday Review, 11 September 1915, p. 246

Moore, Wendy, Endell Street: The Trailblazing Women Who Ran World War One's Most Remarkable Hospital (London: Atlantic, 2020)

Murphy, Andrew, Shakespeare for the People: Working-Class Readers, 1800-1900 (Cambridge: Cambridge University Press, 2008)

Murphy, Sharon, “"Quite Incapable of Appreciating Books Written for Educated Readers": The Mid-Nineteenth-Century British Soldier', in A Return to the Common Reader: Print Culture and the Novel, 1850-1900, ed. by Beth Palmer and Adelene Buckland (Aldershot: Ashgate, 2011), pp. 121-132

'The Nationality of Dickens: Another Impudent German Claim', The Dickensian, 11.6 (June 1915), 161

Peppis, Paul, "“Surrounded by a Multitude of Other Blasts": Vorticism and the Great War', Modernism/Modernity, 4.2 (1997), 39-63

Potter, Jane, Boys in Khaki, Girls in Print: Women's Literary Responses to the Great War 1914-1918 (Oxford: Clarendon Press, 2005)

— 'The British Publishing Industry and the First World War', in The Edinburgh Companion to the First World War and the Arts, ed. by Ann-Marie Einhaus and Katherine Isobel Baxter (Edinburgh: Edinburgh University Press, 2017), pp. 371-384

_ - 'For Country, Conscience and Commerce: Publishers and Publishing, 1914-1918', in Publishing in the First World War: Essays in Book History, ed. by Mary Hammond and Shafquat Towheed (Basingstoke: Palgrave Macmillan, 2007), pp. 11-26 
Reports by the Joint War Committee and the Joint War Finance Committee of the British Red Cross Society: Voluntary Aid Rendered to the Sick and Wounded at Home and Abroad and to British Prisoners of War, 1914-1919 (London: HMSO, 1919)

'The Revival of Leisure for Literature', Publishers' Circular, 12 August 1916, p. 147

Robb, George, British Culture and the First World War, 2nd edn (Basingstoke: Palgrave Macmillan, 2015)

Rose, Jonathan, 'A Conservative Canon: Cultural Lag in British Working-Class Reading Habits', Libraries and Culture, 33.1 (1998), 98-104

Seal, Graham, The Soldiers' Press: Trench Journals in the First World War (Basingstoke: Palgrave Macmillan, 2013)

Seccombe, Thomas, 'Our Shakespeare', The Bookman (April 1916), 7-15

'Shakespeare and Modern Soldiers: Experiences in France', The Times, 23 April 1919 , p. 16

'The Shakespeare Celebrations', The Athenaeum, 4605 (May 1916), p. 220

'Shakespeare in the Trenches: High Standard of Soldiers' Literature', The Scotsman, 27 September 1917, p. 6

Smialkowska, Monika, 'Introduction: Mobilizing Shakespeare During the Great War', Shakespeare, 10.3 (2014), 225-229

'Soldiers and Reading', Edinburgh Evening News, 10 February 1915, p. 4

'Soldiers' Books: The Chief Desires of the Wounded', Falkirk Herald, 12 January 1916, p. 4

'Soldiers' Reading: Books Needed for the Trenches', The Times, 2 April 1915, p. 3

'Soldiers' Stories', Aberdeen Evening Press, 21 January 1915, p. 2

'Some Trench Scenes: A Subaltern's Letters', The Scotsman, 11 September 1915, p. 11

Spiers, Edward M., 'The Regular Army', in A Nation in Arms: A Social Study of the British Army in the First World War, ed. by Ian F. W. Beckett and Keith Simpson (1985; Barnsley: Pen \& Sword, 2004), pp. 37-61

Stevenson, Randall, Literature and the Great War, 1914-1918 (Oxford: Oxford University Press, 2013)

Sutcliffe, Marcella P., 'Reading at the Front: Books and Soldiers in the First World War', Paedagogica Historica, 52.1-2 (2016), 104-120

Taylor, Philip M., British Propaganda in the Twentieth Century: Selling Democracy (Edinburgh: Edinburgh University Press, 1999)

Towheed, Shafquat and Edmund G. C. King, 'Introduction', in Shafquat Towheed and Edmund G. C. King, eds., Reading and the First World War: Readers, Texts, Archives (Basingstoke: Palgrave Macmillan, 2015), pp. 1-25

Todman, Dan, The Great War: Myth and Memory (London: Hambledon Continuum, 2005)

Trott, Vincent, Publishers, Readers and the Great War: Literature and Memory Since 1918 (London: Bloomsbury, 2017) 
Vernon, Arthur, 1917 Diary. Private Papers of A. Vernon, Imperial War Museum, London, Documents.16922

'The War and Reading', Arbroath Herald and Advertiser, 27 April 1917, p. 4 Warren, Herbert, 'The Appeal of Poetry at the Present Hour', The Fortnightly Review (July 1916), 110-123

Watt, Lauchlan MacLean, 'In the Salient: III', Chambers's Journal (18 August 1917), pp. 601-605

Waugh, Arthur, 'Literature and the War', The Fortnightly Review (November 1914), 766-773

'What Soldiers Read: Great Demand for Nat Gould's Novels', Manchester Guardian, 5 January 1916, p. 3

Winter, J. M., 'Britain's “Lost Generation” of the First World War', Population Studies, 31.3 (1977), 449-466

'Woodseats', 'What Soldiers Read', Sheffield Daily Independent, 28 October 1933 , p. 6

Open Access This chapter is licensed under the terms of the Creative Commons Attribution 4.0 International License (http://creativecommons.org/licenses/ by $/ 4.0 /)$, which permits use, sharing, adaptation, distribution and reproduction in any medium or format, as long as you give appropriate credit to the original author(s) and the source, provide a link to the Creative Commons licence and indicate if changes were made.

The images or other third party material in this chapter are included in the chapter's Creative Commons licence, unless indicated otherwise in a credit line to the material. If material is not included in the chapter's Creative Commons licence and your intended use is not permitted by statutory regulation or exceeds the permitted use, you will need to obtain permission directly from the copyright holder.

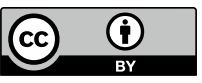

